\title{
Pengaruh Konsumsi Tablet Tambah Darah Terhadap Proses Persalinan dan Kadar Hemoglobin pada Ibu Hamil
}

\author{
Martanty Aditya ${ }^{1}$, Chresiani Destianita Yoedistira ${ }^{2}$ dan Yeni Rahmawati \\ 1,2,3 Program Studi Farmasi, Universitas Ma Chung, Villa Puncak Tidar N-01 Malang, Indonesia, 65151
}

Correspondence: Martanty Aditya (martanty.aditya@machung.ac.id)

Received: 070721 - Revised: 180721 - Accepted: 120821 - Published: 261021

\begin{abstract}
Abstrak. Anemia pada kehamilan dapat menyebabkan dekompensasi kordis, persalinan lambat, keguguran, prematur, syok infeksi dan menyumbang meningkatkatnya Angka Kematian Ibu (AKI). Salah satu program pemerintah untuk menurunkan anemia yaitu dengan pemberian tablet tambah darah (TTD) pada ibu hamil minimal 90 tablet selama kehamilan. Namun masih terdapat hasil yang menunjukan rendahnya kepatuhan konsumsi TTD. Penelitian ini bertujuan untuk mengkonfirmasi kembali efektifitas penggunaan TTD terhadap kadar hemoglobin $(\mathrm{Hb})$ dan pengaruh terhadap proses kelahiran secara normal atau Sectio Caesarea (SC). Penelitian ini menggunakan deskriptif analitik dengan pendekatan cross sectional. Pengambilan data dilakukan secara retrospektif, data diambil melalui rekam medis dan dilanjutkan wawancara terstruktur untuk mengkonfirmasi data rekam medis dan serta karakteristik responden. Data yang diperoleh dikumpulkan melalui Lembar Pengumpul Data (LPD). Penelitian ini dilakukan pada ibu melahirkan yang melakukan pemeriksaan di UPT Puskesmas Sumberpucung Kabupaten Malang pada bulan Maret-Mei 2020. Analisis statistic yang digunakan adalah chi square untuk melihat penggunaan TTD dihubungkan dengan proses persalinan normal atau Sectio Caesarrea serta penggunaan TTD dihubungkan dengan kadar Hb. Uji statistic dianalisis menggunakan perangkat lunak sumber terbuka R studio. Didapatkan 52 subyek yang ikut bersedia dalam penelitian ini dimana terdapat 27 responden $(51.92 \%)$ mengkonsumsi TTD rutin $>3$ bulan dan 25 responden $(48.08 \%)$ sebaliknya. Setelah dilakukan analisis didapatkan hasil seluruh pasien yang mengkonsumsi TTD lebih dari tiga bulan melakukan proses persalinan normal (pvalue $=0,000$ ) dan 26 responden memiliki kadar $\mathrm{Hb}$ normal (pvalue $=0,000$ ). Dari penelitian ini dapat disimpulkan bahwa konsumsi TTD lebih dari tiga bulan menngurangi risiko kehamilan SC dan juga kejadian anemia.
\end{abstract}

Kata kunci: Anemia, Ibu Hamil, Sectio Caeserea, Tablet tambah darah

Citation Format: Aditya, M., Yoedistira, C.D., dan Rahmawati, Y. (2020). Pengaruh Konsumsi Tablet Tambah Darah Terhadap Proses Persalinan dan Kadar Hemoglobin pada Ibu Hamil. Prosiding Seminar Nasional Abdimas Ma Chung (SENAM), 2021, 30-37 


\section{PENDAHULUAN}

Angka Kematian Ibu (AKI) merupakan suatu indikator dalam melihat keberhasilan untuk peningkatan upaya kesehatan serta menilai derajat kesehatan masyarakat. AKI menjadi indikator terhadap peningkatan pelayanan kesehatan baik dari sisi aksesibilitas maupun kualitas. AKI merupakan rasio kematian ibu selama kehamilan, persalinan, dan nifas disetiap 100.000 kelahiran hidup (Indonesia, 2021). Penyebab utama tejadinya AKI adalah Anemia. Efek yang timbul akibat anemia yaitu menyebabkan dekompensasi kordis, kelahiran premature, berat bayi rendah, syok infeksi baik saat bersalin atau paska bersalin (Stephen et al., 2018). Kasus anemia sendiri terus meningkat dimana pada tahun 2018 menjadi 48.9\% (Kemenkes RI, 2018). Pemerintah melakukan upaya pencegahan dan penanggulangan anemia gizi besi dengan pemberian Tablet Tambah Darah (TTD) yang diprioritaskan pada ibu hamil, diberikan dengan dosis pemberian sehari 1 (satu) tablet selama minimal 90 hari selama kehamilan, diminum setiap hari (Kementerian Kesehatan Republik Indonesia, 2020). Saat ini terdapat penelitian yang menghubungkan antara kepatuhan TTD dengan pengetahuan (Anggraeni, 2019), ataupun adanya intervensi pendampingan dalam mengkonsumsi TTD (Aditianti et al., 2015), serta hubungan dengan status anemia (Fiqriah Ayu Awalamaroh, Leni Sri Rahayu, 2018) namun belum ada yang menghubungkan dengan proses persalinan. Oleh karena itu penelitian ini dilakukan yang pertama untuk mengetahui hubungan konsumsi TTD rutin minimal 90 tablet dengan proses persalinan. Tujuan selanjutnya adalah untuk mengetahui hubungan konsumsi TTD rutin minimal 90 tablet dengan kejadian anemia dengan melihat kadar Hemoglobin ( $\mathrm{Hb})$. Dalam penelitian ini factor pengganggu dari karakteristik responden juga ikut dianalisis.

\section{METODE PELAKSANAAN}

Rancangan dalam penelitian ini menggunakan deskriptif analitik yang dilakukan dengan pendekatan cross sectional dan pengambilan data retrospektif. Waktu penelitian Maret-Mei 2020 di Puskesmas Sumberpucung. Populasi dan sampel dalam penelitian adalah seluruh ibu hamil yang telah melahirkan dan melakukan pemeriksaan kehamilan setelah melahirkan pada bulan Januari-April 2020.

Variabel bebas dalam penelitian ini adalah jumlah konsumsi TTD yang dibagi dalam 2 kelompok yaitu rutin $>3$ bulan dan tidak rutin $<3$ bulan. Variabel terikat pertama yang diukur adalah kadar $\mathrm{Hb}$ dikatakan normal bila nilainya adalah $10-12 \mathrm{mg} / \mathrm{dL}$ dan tidak normal bila kadar $\mathrm{Hb}<10 \mathrm{mg} / \mathrm{dL}$ pada ibu hamil setelah mengkonsumsi TTD. Variabel 
terikat yang kedua adalah proses persalinan normal atau SC. Variabel pengganggu yang ikut diteliti adalah usia, asuransi kesehatan, pendidikan, pekerjaan ibu, pekerjaan suami, usia suami, penghasilan keluarga, melahirkan anak ke-, tinggal Bersama, berat badan bayi, waktu minum obat TTD, efek TTD, makan buah sayur, obat lain yang dikonsumsi, riwayat kehamilan sebelumnya dan riwayat penyakit.

Data diperoleh melalui rekam medis dan dilanjutkan dengan wawancara terstruktur. Seluruh data yang didapatkan dikumpulkan melalui lembar pengumpul data.

Data yang diperoleh selanjutnya dianalisis dengan uji chi square. Analisis yang pertama untuk melihat hubungan antara konsumsi TTD rutin dengan dengan karakteristik responden. Analisis yang kedua melihat hubungan konsumsi rutin dengan proses persalinan dan selanjutnya melihat hubungan konsumsi TTD rutin dengan kejadian anemia. Uji analisis dilakukan dengan perangkat lunak sumber terbuka (R Core Team, 2012).

\section{HASIL DAN PEMBAHASAN}

Penelitian ini dilakukan di Puskesmas Sumberpucung dan telah mendapatkan ijin dari Dinkes Kabupaten Malang No 070/1335/35.07.103/2020. Penelitian ini juga telah melalui ethical clearance dan dinyatakan layak etik. Pasien yang memenuhi kriteria inklusi mendapatkan informed consent dan selanjutnya penandatanganan yang menyatakan ikut serta dalam penelitian ini.

Sampel yang diperoleh adalah 52 responden ibu hamil dan melanjutkan kontrol setelah melahirkan di tempat penelitian. Responden selanjutnya dikelompokan menjadi rutin konsumsi TTD >3 bulan yaitu 27 responden (51.92\%) dan tidak rutin mengonsumsi TTD $<3$ bulan diperoleh 25 responden $(48.08 \%)$. Seluruh responden tersebut bersedia diambil datanya dan tidak ada yang mengundurkan diri. Data demografi yang diperoleh selanjutnya direkap dan karakteristik responden dideskripsikan dalam bentuk prosentase dan disajikan melalui Tabel 1. Tabel tersebut menggambarkan sebaran karakteristik responden pada kelompok rutin konsumsi TTD dan tidak rutin konsumsi TTD. Selanjutnya dilakukan analisis untuk melihat hubungan faktor pengganggu dengan konsumsi TTD dan didapatkan bahwa terdapat dua faktor penggangu yang memiliki hubungan yang pertama konsusmi TTD dengan pekerjaan ibu (pvalue $=0.029$ ). Hubungan yang kedua terdapat hubungan efek mual penggunaan TTD dengan konsumsi TTD (pvalue $=0.002$ ). 
Tabel 1. Karaktristik Demografi Responden

\begin{tabular}{|c|c|c|c|c|}
\hline No & Karakteristik Responden & $\begin{array}{c}\text { TTD Rutin } \\
\mathrm{n}=27(51.92 \%)\end{array}$ & $\begin{array}{c}\text { TTD Tidak Rutin } \\
\mathrm{n}=25(48.08 \%)\end{array}$ & $p$-value \\
\hline \multirow[t]{4}{*}{1.} & Usia (tahun) & & & \\
\hline & $<20$ & $2(3.85 \%)$ & $1(1.92 \%)$ & \\
\hline & $20-30$ & $12(23.08 \%)$ & $15(28.85 \%)$ & 0.517 \\
\hline & $31-40$ & $13(25.00 \%)$ & $9(17.31 \%)$ & \\
\hline \multirow[t]{3}{*}{2.} & Asuransi & & & \\
\hline & Tidak Memiliki BPJS & $9(17.31 \%)$ & $4(7.69 \%)$ & 0.262 \\
\hline & BPJS & $18(34.61 \%)$ & $21(40.38 \%)$ & \\
\hline \multirow[t]{4}{*}{3.} & Pendidikan & & & \\
\hline & SLTP & $9(17.31 \%)$ & $4(7.69 \%)$ & \\
\hline & SLTA & $17(32.69 \%)$ & $20(38.46 \%)$ & 0.351 \\
\hline & Perguruan Tinggi & $1(1.92 \%)$ & $1(1.92 \%)$ & \\
\hline \multirow[t]{3}{*}{4.} & Pekerjaan Ibu & & & \\
\hline & Bekerja & $2(3.85 \%)$ & $9(17.31 \%)$ & $0.029 *$ \\
\hline & Tidak Bekerja & $25(48.08 \%)$ & $16(30.77 \%)$ & \\
\hline \multirow[t]{4}{*}{5.} & Usia Suami & & & \\
\hline & $20-30$ & $10(19.23 \%)$ & $11(21.15 \%)$ & \\
\hline & $31-40$ & $12(23.08 \%)$ & $13(25 \%)$ & 0.262 \\
\hline & $41-50$ & $5(10 \%)$ & $1(1.92 \%)$ & \\
\hline \multirow[t]{5}{*}{6.} & Penghasilan & & & \\
\hline & $<1,5$ Juta & $4(7.69 \%)$ & $2(3.85 \%)$ & \\
\hline & $1,5-2,5$ Juta & $10(19.23 \%)$ & $15(28.85 \%)$ & 0.254 \\
\hline & $>2,5-4 \mathrm{Juta}$ & $11(21.15 \%)$ & $8(15.38 \%)$ & \\
\hline & $>4$ Juta & $2(3.85 \%)$ & $0(0 \%)$ & \\
\hline \multirow[t]{3}{*}{7.} & Pekerjaan Suami & & & \\
\hline & Swasta/Wiraswasta & $23(44.23 \%)$ & $0(0 \%)$ & 0.138 \\
\hline & PNS & $4(7.69 \%)$ & $25(48.08 \%)$ & \\
\hline \multirow[t]{5}{*}{8.} & Anak Ke & & & \\
\hline & Satu & $7(13.46 \%)$ & $10(19.23 \%)$ & \\
\hline & Dua & $12(23.08 \%)$ & $11(21.15 \%)$ & 0.475 \\
\hline & Tiga & $6(11.54 \%)$ & $2(3.85 \%)$ & \\
\hline & Empat & $2(3.85 \%)$ & $2(3.85 \%)$ & \\
\hline
\end{tabular}


Tabel 1. Lanjutan

9. Jarak Kelahiran (Tahun)

\begin{tabular}{|c|c|c|c|c|}
\hline & 0 & $7(13.46 \%)$ & $10(19.23 \%)$ & \multirow{3}{*}{0.545} \\
\hline & $1-2$ & $6(11.54 \%)$ & $5(9.61 \%)$ & \\
\hline & $3-4$ & $14(26.92 \%)$ & $10(19 \%)$ & \\
\hline \multicolumn{5}{|c|}{$\begin{array}{ll}\text { 10. } & \text { Tinggal Bersama }\end{array}$} \\
\hline & Sendiri & $18(34.61 \%)$ & $19(36.54 \%)$ & \multirow[t]{2}{*}{0.662} \\
\hline & Bersama Ortu & $9(17.31 \%)$ & $6(11.54 \%)$ & \\
\hline & Berat Badan Bayi & & & \multirow{4}{*}{0.849} \\
\hline & $<2600$ & $3(5.77 \%)$ & $2(3.85 \%)$ & \\
\hline & $2600-3500$ & $19(36.54 \%)$ & $17(32.69 \%)$ & \\
\hline & $>3500$ & $5(9.61 \%)$ & $6(11.54 \%)$ & \\
\hline
\end{tabular}

0.545

12. Waktu Minum Obat

$\begin{array}{lccc}\text { Pagi } & 2(3.85 \%) & 14(26.92 \%) & \\ \text { Siang } & 2(3.85 \%) & 6(11.54 \%) & 0.119 \\ \text { Sore } & 3(5.77 \%) & 2(3.85 \%) & \\ \text { Malam } & 20(38.46 \%) & 3(5.77 \%) & \end{array}$

13. Efek TTD

$\begin{array}{lccc}\text { Mual } & 5(9.61 \%) & 16(30.77 \%) & 0.002 * \\ \text { Tidak Mual } & 22(42.31 \%) & 9(17.31 \%) & \end{array}$

\begin{tabular}{cccc}
\hline 14. Makan Buah Sayur & & \\
Sedang & $7(13.46 \%)$ & $9(17.31 \%)$ & 0.267 \\
Sering & $20(38.46 \%)$ & $16(30.77 \%)$ & \\
\hline
\end{tabular}

15. Obat Lain yang di Minum

$\begin{array}{lccc}\text { Ada } & 3(5.77 \%) & 3(5.77 \%) & 1 \\ \text { Tidak Ada } & 24(46.15 \%) & 22(42.31 \%) & \end{array}$

\begin{tabular}{|c|c|c|c|c|}
\hline \multicolumn{5}{|c|}{ 16. Riwayat Kehamilan } \\
\hline & $\mathrm{SC}$ & $19(36.54 \%)$ & $15(28.85 \%)$ & 0.621 \\
\hline & Normal & $8(15.38 \%)$ & $10(19.23 \%)$ & \\
\hline \multicolumn{5}{|c|}{ Riwayat Penyakit } \\
\hline & Ada & $0(0 \%)$ & $0(0 \%)$ & 0.621 \\
\hline & Tidak Ada & $27(51.92 \%)$ & $25(48.08 \%)$ & \\
\hline
\end{tabular}

Selanjutnya dilakukan analisis untuk melihat hubungan antara variable bebas dan variabel terikat. Pada Tabel 2 disajikan hasil yang meilhat hubungan antara konsumsi TTD 
dengan proses persalinan. Hasil menunjukan pasien yang mengkonsumsi TTD rutin $>$ 3bulan seluruhnya menjalani proses persalinan normal $(p$-value $=0.000)$

Tabel 2. Hubungan penggunaan TTD dengan proses persalinan

\begin{tabular}{lccc}
\hline & Persalinan SC & Persalinan normal & $p$-value \\
\hline TTD > 3 Bulan & $3(5.77 \%)$ & $27(51.92 \%)$ & 0.000 \\
\cline { 1 - 3 } TTD < 3 Bulan & $22(42.31 \%)$ & $0(0 \%)$ & \\
\hline
\end{tabular}

Pada Tabel 3 disajikan hasil yang melihat hubungan antara konsumsi TTD dengan kadar $\mathrm{Hb}$. Hasil menunjukan pasien yang mengkonsumsi TTD rutin >3bulan didominasi dengan kadar $\mathrm{Hb}$ normal ( $p$-value $=0.000)$ yaitu 26 responden $(50 \%)$ hanya 1 responden dengan kadar $\mathrm{Hb}$ tidak normal (1.92\%).

Tabel 3. Hubungan penggunaan TTD dengan kadar $\mathrm{Hb}$

\begin{tabular}{lccc}
\hline & Hb normal & Hb tidak normal & $p$-value \\
\hline TTD > 3 Bulan & $26(50 \%)$ & $1(1.92 \%)$ & 0.000 \\
\cline { 1 - 3 } TTD < 3 Bulan & $3(5.77 \%)$ & $22(42.31 \%)$ & \\
\hline
\end{tabular}

TTD merupakan suplemen yang mengandung zat besi dan asam folat dimana zat besi dan asam folat akan membentuk hemoglobin menempel di eritrosit sehingga hemoglobin naik dan mengikat oksigen untuk diedarkan ke seluruh tubuh. Ibu hamil dengan konsumsi TTD $<3$ bulan berpengaruh pada proses persalinan SC karena efek dari anemia menyebabkan gangguan kontraksi rahim saat persalinan dan juga penurunan konsentrasi $\mathrm{Hb}$ selama proses persalinan. Besi sangat berperan penting dalam memproduksi energi, sintesis DNA dan proliferasi sel (Drukker et al., 2015; Dündar, 2019).

Kepatuhan ibu hamil mengkonsumsi TTD merupakan faktor penting untuk pencegahan terjadinya anemia. Penelitian sebelumnya menunjukan kepatuhan mengkonsumsi TTD masih rendah yang merupakan salah satu faktor penyebab anemia defisiensi zat besi. Faktor-faktor yang mempengaruhi kepatuhan ibu hamil mengkonsumsi TTD adalah sedikitnya pengetahuan tentang pentingnya TTD, faktor lupa minum, takut bayi menjadi besar, kesadaran yang kurang mengenai bahaya anemia yang ditimbulkan bagi ibu hamil dan bayi, serta adanya efek mual atau pusing yang ditimbulkan setelah mengkonsumsi TTD (Assefa et al., 2019; Boti et al., 2018; Fouelifack et al., 2019). 
Diharapkan dengan penelitian ini bisa memberikan informasi kepada teman sejawat untuk mengedukasi pentingnya konsumsi TTD selama masa kehamilan. Konseling untuk suami atau keluarga supaya lebih memperhatikan ibu hamil agar bisa rutin mengonsumsi TTD selama kehamilan.

\section{KESIMPULAN}

Konsumsi TTD rutin lebih dari tiga bulan meningkatkan proses persalinan normal (pvalue $=0,000)$ dan mengurangi risiko SC. Selain itu juga ibu hamil yang rutin mengkonsumsi memiliki kadar $\mathrm{Hb}$ normal (pvalue $=0,000$ ) sehingga mengurangi risiko kejadian anemia. Untuk selanjutnya perlu dilakukan edukasi untuk meningkatkan pengetahuan terkait pentingnya konsumsi TTD baik terhadap ibu hamil maupun keluarga sebagai pendamping.

\section{UCAPAN TERIMA KASIH}

Ucapan terima kasih ditujukan khususnya kepada Dinas Kesehatan Kabupaten Malang dan UPT Puskesmas Sumber Pucung serta Universitas Ma Chung yang mengijinkan terlaksananya penelitian ini.

\section{DAFTAR PUSTAKA}

Aditianti, A., Permanasari, Y., \& Julianti, E. D. (2015). Pendampingan Minum Tablet Tambah Darah (Ttd) Dapat Meningkatkan Kepatuhan Konsumsi Ttd Pada Ibu Hamil Anemia. Penelitian Gizi Dan Makanan (The Journal of Nutrition and Food Research), 38(1), 71-78. https://doi.org/10.22435/pgm.v38i1.4424.71-78

Anggraeni, S. (2019). Faktor - Faktor Yang Memengaruhi Kepatuhan Ibu Hamil Mengonsumsi Tablet Fe Di Bpm Isniwati Sukoharjo. Media Ilmu Kesehata, 8(1), 64 70. https://doi.org/10.30989/mik.v8i1.381

Assefa, H., Abebe, S. M., \& Sisay, M. (2019). Magnitude and factors associated with adherence to Iron and folic acid supplementation among pregnant women in Aykel town, Northwest Ethiopia. BMC Pregnancy and Childbirth, 19(1), 1-8. https://doi.org/10.1186/s12884-019-2422-4

Boti, N., Bekele, T., Godana, W., Getahun, E., Gebremeskel, F., Tsegaye, B., \& Oumer, B. (2018). Adherence to Iron-Folate Supplementation and Associated Factors among Pastoralist's Pregnant Women in Burji Districts, Segen Area People's Zone, Southern Ethiopia: Community-Based Cross-Sectional Study. International Journal of Reproductive Medicine, 2018, 1-8. https://doi.org/10.1155/2018/2365362

Drukker, L., Hants, Y., Farkash, R., Ruchlemer, R., Samueloff, A., \& Grisaru-Granovsky, S. (2015). Iron deficiency anemia at admission for labor and delivery is associated with an increased risk for Cesarean section and adverse maternal and neonatal 
outcomes. Transfusion, 55(12), 2799-2806. https://doi.org/10.1111/trf.13252

Dündar, B. (2019). The Prevalence And Analysis Of Risk Factors For Postpartum Anemia In Women Without Prepartum Anemia. Haydarpasa Numune Training and Research Hospital Medical Journal, 59(2), 165-170. https://doi.org/10.14744/hnhj.2019.75436

Fiqriah Ayu Awalamaroh, Leni Sri Rahayu, dan I. Y. (2018). Kepatuhan Mengonsumsi Tablet FE Berhubungan Dengan Status Anemia Pada Ibu Hamil. ARGIPA (Arsip Gizi Dan Pangan), 3(2), 80-90.

Fouelifack, F. Y., Sama, J. D., \& Sone, C. E. (2019). Assessment of adherence to iron supplementation among pregnant women in the yaounde gynaeco-obstetric and paediatric hospital. Pan African Medical Journal, 34, 1-8. https://doi.org/10.11604/pamj.2019.34.211.16446

Indonesia, K. K. R. (2021). Profil Kesehatan Indonesia 2020. In Kementrian Kesehatan Republik Indonesia.

Kemenkes RI. (2018). Laporan Nasional Riset Kesehatan Dasar 2018.pdf. In Badan Penelitian dan Pengembangan Kesehatan (p. 198).

Kementerian Kesehatan Republik Indonesia. (2020). Pedoman Pemberian Tablet Tambah Darah (TTD) Bagi Ibu Hamil. 24.

R Core Team. (2012). R: A Language and Environment for Statistical Computing. In Vienna, Austria: $R$ Foundation for Statistical Computing (p. R Foundation for Statistical Computing, Vienna, Au).

Stephen, G., Mgongo, M., Hussein Hashim, T., Katanga, J., Stray-Pedersen, B., \& Msuya, S. E. (2018). Anaemia in Pregnancy: Prevalence, Risk Factors, and Adverse Perinatal Outcomes in Northern Tanzania. Anemia, 2018. https://doi.org/10.1155/2018/1846280

(C) 2021 by authors. Content on this article is licensed under a Creative Commons Attribution 4.0 International license. (http://creativecommons.org/licenses/by/4.0/). 